Hal 40-48

\title{
OPTIMALISASI PEMANFAATAN PANGKALAN PENDARATAN IKAN (PPI) BEBA GALESONG UTARA KABUPATEN TAKALAR SULAWESI SELATAN
}

\author{
Optimization of Utilization In Beba Galesong Utara Fishing Port, Takalar \\ Regency Sulawesi Selatan Province. \\ oleh: \\ Asmiati Salim ${ }^{1)}$, Danial ${ }^{2)}$ dan Ihsan ${ }^{3)}$ \\ 1) Dinas Kelautan dan Perikanan Provinsi Sulawesi Selatan \\ 2) Program Studi Ilmu Kelautan FPIK UMI \\ 3) Program Studi Pemanfaatan Sumberdaya Perikanan FPIK UMI \\ Korespondensi: asmiatifarsyah@gmail.com. \\ Diterima: tanggal 5 November 2018; Disetujui 30 November 2018
}

\begin{abstract}
Optimization of utilization in Beba Galesong Utara fishing port, Takalar Regency. Asmiati Salim, Marine and fisheries office of Sulawesi Selatan Province. Under supervision of Danial and Ihsan. It is important to have appropriate facility in order to support Fishing Port working progress in Bebu Galesong Utara fishing port. Incapacity one of the facility could obstruct the activity in that particular location. This problem frequently found in many fishing port in Indonesia. Beba Fishing Port is one of 23 Fishing port which contribute to original local government revenue in Sulawesi Selatan. The aim of this study is to analyze Beba fishing Port Facility for its development and optimizing under utilization facility. Methods used in this study includes various survey methods to gather fact and indication to find factual information about institution, social, economy, and politics in Beba Fishing Port. Descriptive analysis used in identifying towards existing facility and activity includes renumeration on fish auction facility, port and shipping pools. The result show, based on thirteen existing port activity included in Minesterial Decree No. 08/MEN/2012 regarding Fishing Port Affairs. Conclusion of the study shows that Facility in Beba Fishing Port in underutilization.
\end{abstract}

Keyword: Optimization, Port, Beba, at Takalar District

\begin{abstract}
ABSTRAK
Dalam menunjang kelancaran aktivitas Pangkalan Pendaratan Ikan Beba di perlukan dukungan fasilitas yang memadai. Tidak beroperasionalnya salah satu fasilitas akan menghambat kelancaran aktivitas pelabuhan tersebut. Permasalahan ini sering ditemukan pada banyak pelabuhan perikanan. PPI Beba merupakan salah satu dari 23 PPI di yang ada di Provinsi Sulawesi Selatan yang dapat memberikan kontribusi Pendapatan Asli Daerah. Tujuan penelitian ini Menganalisis fasilitas Pangakalan Pendaratan Ikan Beba untuk pengembangngannya dan Mengoptimalkan fasilitas Pangakalan Pendaratan Ikan Beba yang belum termanfaatkan. Metode penelitian adalah metode survei. berupa penyelidikan yang diadakan untuk memperoleh fakta-fakta dari gejala-gejala yang ada dan mencari keterangan-keterangan secara faktual, baik tentang institusi, sosial, ekonomi atau politik di daerah Pangkalan Pendaratan Ikan Beba kemudian melakukan analisis secara deskriptif sebelumnya dilakukan identifikasi terhadap fasilitas dan aktivitas yang ada dan penghitungan kembali kapasitas tempat pelelangan ikan, dermaga dan kolam pelabuhan. Hasil penelitian menunjukkan bahwa berdasarkan tiga belas jenis aktivitas kepelabuhanan perikanan yang tercantum dalam No: PER.08/MEN/2012 tentang kepelabuhanan perikanan, maka permasalahan di PPI Beba fasilitas masih terdapat sarana dan prasarana yang belum termanfaatkan secara optimal.
\end{abstract}

Kata kunci: Optimalisasi, Pelabuhan, Beba, Kabupaten Takalar 


\section{PENDAHULUAN}

Pembangunan pelabuhan perikanan merupakan salah satu unsur penting dalam peningkatan infrastruktur perikanan dan bagian dari sistem perikanan tangkap. Adanya pelabuhan perikanan akan mendorong aktivitas perikanan tangkap lebih teratur dan terarah. Pelabuhan perikanan bukan hanya sebatas menyediakan fasilitas untuk aktivitas pendaratan, pengolahan dan pendistribusian hasil tangkapan tetapi juga memberikan pelayanan yang optimal terhadap nelayan sebagai pengguna fasilitas yang tersedia sesuai dengan fungsinya (Atharis 2008).

Provinsi Sulawesi Selatan secara geografis terletak di titik $0^{\circ} 12^{\prime}-8^{\circ}$ Lintang Selatan dan $116^{\circ} 48^{\prime}-122^{\circ} 36^{\prime}$ Bujur Timur. Luas Wilayahnya $62.482,54 \mathrm{~km}^{2}$ (42\% dari luas seluruh pulau Sulawesi dan 4,1 \% dari luas seluruh Indonesia). Secara geogrofis merupakan Center Point of Indonesian memiliki 24 kab/kota, dimana 18 kab/kota merupakan pesisir dengan panjang garis pantai mencapai 1.937 Km. Wilayah Pengelolaan Perikanan (WPP RI 713) yang meliputi Selat Makassar, Teluk Bone dan laut Flores. Jumlah pelabuhan perikanan yang ada di Sulawesi Selatan sebanyak 23 Pelabuhan dan yang tidak beroperasi sebanyak 2 pelabuhan (BPS Sulsel, 2017).

Salah Satu PPI yang ada di Suawesi Selatan adalah PPI Beba merupakan pangkalan pendaratan ikan tipe D yang terletak di Galesong Utara yang memiliki posisi yang strategis karna dekat dengan kabupaten Gowa dan
Kota Makassar sehingga dalam RTWRW Kabupaten Takalar sebagai penunjang kota Makassar, memiliki potensi ekonomi yang besar untuk dikembangkan khususnya sumberdaya pesisir dan laut. Penelitian ini bertujuan untuk menganalisis fasilitas Pangkalan Pendaratan Ikan Beba untuk pengembangngannya dan apakah Fasilitas PPI Beba sudah optimal dalam pemanfaatanya.

\section{METODE PENELITIAN}

Penelitian ini dilaksanakan selama 2 bulan yaitu bulan Agustus s/d September 2018. Data yang digunakan dalam penelitian ini terdiri dari data primer dan sekunder. Pengumpulan data dilakukan melalui pengamatan langsung dan pengisian kuesioner serta wawancara terhadap responden untuk mengetahui kondisi fisik, kapasitas dan ukuran fasilitas pokok (dermaga, kolam pelabuhan) dan fasilitas fungsional (gedung TPI).

Penentuan jumlah responden dilakukan secara purposive sampling kepada pihak pengelola PPI (2 orang) untuk mengetahui fasilitas yang tersedia (jenis, ukuran dan kapasitasnya); produksi hasil tangkapan yang didaratkan; nelayan (6 orang) untuk mengetahui jenis dan ukuran armada penangkapan serta kapasitas palkanya; besarnya produksi hasil tangkapan per trip penangkapan dan sistem penjualannya, rata-rata jumlah kapal bongkar ikan per hari; fishing trip menurut jenis kapal dan alat tangkap serta permasalahan terhadap PPI terkait dengan fasilitasnya; pedagang (3 orang) 
untuk mengetahui sistem pembelian ikan, volume pembelian ikan, harga ikan per $\mathrm{kg}$ untuk tiap jenisnya, bahan dan alat yang digunakan untuk menjaga mutu hasil tangkapan, fasilitas yang dimiliki untuk menyimpan sementara hasil tangkapan dan permasalahan terhadap fasilitas tempat pelelangan ikan.

Data sekunder dikumpulkan dari beberapa instansi terkait yaitu pengelola PPI Beba; Dinas Perikanan dan Kelautan Kabupaten Takalar ; Dinas Perikanan Provinsi Sulawesi Selatan dan Badan Perencanaan Daerah Kabupaten Takalar. Keseluruhan data dianalisis dengan menggunakan formulasi sebagai berikut:

a. Analisis fasilitas Pangkalan Pendaratan Ikan (PPI) Beba dan kemungkinan pengembangannya

Penggunaan fasilitas yang ada dapat diketahui dengan menggunakan analisis pemanfaatan. Analisis pemanfaatan fasilitas pelabuhan perikanan berdasarkan Dirjen Perikanan (1981) diacu dalam Suherman (2007), sebagai berikut:

1) Kolam pelabuhan

a) Luas kolam pelabuhan

$$
L=L t+(3 \times n \times l \times b) \text { : dimana } L t=\pi r^{2}
$$

Keterangan:

$L$ : luas kolam pelabuhan $\left(\mathrm{m}^{2}\right)$

Lt : luas untuk memutar kapal $\left(\mathrm{m}^{2}\right)$

$r$ : panjang kapal terbesar (m),

$\pi: 3,14$

$n$ : jumlah kapal maksimum yang berlabuh $l$ : panjang rata-rata kapal (m)

$b$ : lebar kapal terbesar (m),

b) Kedalaman kolam

$$
D=d+0,5 h+s+h+c
$$

Keterangan:

$D \quad$ : kedalaman perairan $(\mathrm{cm})$

d : draft kapal terbesar

(cm), draft kapal ukuran 25 GT

$h \quad$ : tinggi pasang maksimum (cm), tinggi pasang di kolam (cm)

$s$ : squat, tinggi ayunan kapal yang melaju $(20 \mathrm{~cm})$

c : clearance, jarak aman

lunas kapal ke dasar perairan $(100 \mathrm{~cm})$

2) Dermaga

Panjang dermaga yang dibutuhkan

dihitung dengan rumus:

$$
L=\frac{(1+\mathrm{s}) \times \mathrm{n} \times \mathrm{axh}}{\mathrm{u} \times \mathrm{d}}
$$

Keterangan:

$L$ : panjang dermaga $(\mathrm{m})$

$l$ : lebar kapal rata-rata $(4 \mathrm{~m})$

$s$ : jarak antar kapal (7 m)

$n$ : jumlah kapal yang memakai dermaga rata-rata per hari (20 kapal)

$a$ : berat rata-rata kapal (ton), berat kapal rata-rata untuk kapal <30 GT menurut Pujo et al. (2012) yaitu 15 ton.

$h$ : lama kapal di dermaga (jam), waktu yang digunakan dalam bersandar

$u$ : produksi rata-rata (ton)

$d$ : lama fishing trip rata-rata (jam) 
3) Gedung pelelangan

Murdiyanto (2004); dalam Danial, (2017) rumus yang dipakai untuk menentukan luas gedung pelelangan adalah sebagai berikut:

$$
S=\frac{\mathrm{N} \times \mathrm{P}}{\mathrm{R} \times \mathrm{a}}
$$

Keterangan:

$S$ : luas gedung pelelangan $\left(\mathrm{m}^{2}\right)$

$N$ : jumlah produksi per hari (ton)

$P$ : faktor daya tampung ruang terhadap produksi (ton $\left./ \mathrm{m}^{2}\right)$,

$\alpha$ : rasio antara ruang lelang dan gedung pelelangan

$\mathrm{R}$ : frekuensi pelelangan per hari

4) Lahan pelabuhan perikanan

Lahan pelabuhan yang digunakan adalah 2-4 kali luas keseluruhan dari fasilitas yang ada. Hasil perhitungan selanjutnya dibandingkan dengan kapasitasnya sehingga didapatkan apakah sarana perlu diperluas atau tidak.

5) Areal tempat parkir Luas tempat parkir yang dibutuhkan dihitung dengan menggunakan rumus:

$$
L=\frac{\mathrm{P} \times \mathrm{R}}{\mathrm{N} \times \mathrm{D}}
$$

Keterangan:

$$
\begin{aligned}
P / N & \text { jumlah produksi rata- } \\
& \text { rata per hari dalam } 1 \\
& \text { tahun (ton) } \\
\mathrm{D}: & \text { daya angkut tiap } \\
& \text { ken- daraan (ton) }
\end{aligned}
$$

$\mathrm{R}$ : luas tempat parkir saat ini $\left(\mathrm{m}^{2}\right)$ $\mathrm{L}$ : luas tempat parkir yang dibutuhkan $\left(\mathrm{m}^{2}\right)$

6) Tata Kelola Fasilitas

Tata kelola fasilitas pokok, fasilitas fungsional dan fasilitas penunjang dianalisis secara deskriptif mulai dari tata letak fasilitas dan prosedur penggunaan fasilitas di PPI Beba.

B. Analisis Optimalisasi Pemanfaatan Fasilitas Pangkalan Pendaratan Ikan (PPI) Beba.

Menurut Lubis (2012), bahwa batasan untuk mengetahui pemanfaatan pelabuhan dapat dilakukan dengan membandingkan pengguna fasilitas dengan Kapasitas adapun formulasi sebagai berikut:

$$
\text { Tingkat Pemanfaatan }=\frac{\text { Penggunaan fasilitas }}{\text { Kapasitas fasilitas }} \quad \times 100 \%
$$

Jika dari perhitungan didapatkan :

- prosentasi pemanfaatan $>100 \%$, tingkat pendayagunaan fasilitas melampaui kondisi optimal

- prosentasi pemanfaatan $=100 \%$, tingkat pendayagunaan fasilitas mencapai kondisi optimal

- prosentasi pemanfaatan $<100 \%$, tingkat pendayagunaan fasilitas belum mencapai optimal.

Dalam analisis ini fasilitas yang kapasitasnya tidak tentu, maka besarnya pemanfaatan dipertimbangkan secara subjektif. 
HASIL DAN PEMBAHASAN

\section{Analisis Pemanfaatan Fasilitas PPI Beba}

Dermaga merupakan tempat bersandarnya kapal untuk melakukan aktivitas di pelabuhan. Berdasarkan data yang didapatkan pada saat survey lapangan lebar kapal rata - rata yaitu 5 m, sedangkan jarak antar kapal yaitu 1 $m$, kemudian jumlah kapal yang menggunakan dermaga PPI Beba hanya 3-5 kapal perharinya. Sedangkan berat rata - rata kapal untuk dibawah 30 GT menurut Pujo et al. (2012) yaitu 15 ton, lalu kapal kapal tersebut menggunakan dermaga dengan waktu 4 jam. Produksi rata - rata yaitu 10 ton dan rentan waktu melakukan proses penangkapan yaitu 10 jam. Berdasarkan Hasil analisis diatas maka dapat diketahui bahwa panjang dermaga yang dibutuhkan adalah 10.8 meter. Jika dibandingkan dermaga yang tersedia maka masih terdapat $51,7 \mathrm{~m}$ yang belum dimanfaatkan oleh nelayan. Panjang dermaga PPI Beba telah memenuhi kriteria teknis PPI Berdasarkan Peraturan Menteri Kelautan dan Perikanan No. 8 Tahun 2012 yaitu panjang dermaga sekurang-kurangnya 50 m sehingga standar Dermaga PPI Beba disimpaikan sudah sesuai dengan standar yang di tetapkan namun dermaga belum di lengkapi karet pengaman dan tempat mengikat kapal pada saat kapal bersandar di dermaga sehingga badan kapal mudah rusak.

\begin{tabular}{lll} 
Dari & Analisis & \multicolumn{2}{c}{ Pemanfaatan } \\
disampaikan & Panjang & dermaga yang \\
dimanfaatkan & adalah 10.8 meter dan \\
analisis pemanfaatanya sebesar $17,28 \%$.
\end{tabular}

Jika dibandingkan dengan panjang dermaga sebesar 68.3 yang tersedia maka masih terdapat $57,7 \mathrm{~m}$ yang belum termanfaatkan, Lahan seluas $12.200 \mathrm{~m} 2$ atau setara dengan 1,22 $\mathrm{Ha}$ dan analisis pemanfaatannya PPI Beba seluas 2.670 $\mathrm{m} 2$ dan tingkat optimalisasi lahan hanya $21.88 \%$, tingkat pemanfaatan areal tempat parkir memiliki persentase sebesar 27,8 \%, luas TPI yang telah ada yaitu $210 \mathrm{~m} 2$ pemanfaatan tempat pelelangan ikan di PPI Beba sebesar 0\%.

Gedung pelelangan merupakan suatu tempat yang berfungsi sebagai tempat para nelayan melakukan proses jual beli ikan. PPI Beba memiliki TPI dengan Jumlah produksi rata - rata per hari yaitu 10 ton sedangkan daya tampung ruang terhadap produksi yaitu 20 ton . Berdasarkan hasil analisis luas TPI menunjukkan bahwa luas yang dibutuhkan untuk tempat pelelangan ikan ialah $200 \mathrm{~m}^{2}$. Hal ini menunjukkan bahwa luas yang dibutuhkan hampir sama dengan luas TPI yang telah ada yaitu 210 $\mathrm{m}^{2}$. TPI Beba telah memenuhi standar kriteria luas tempat pelelangan ikan, hal ini didukung oleh pernyataan Lubis (2012) yang menyatakan bahwa standar kriteria untuk luas TPI untuk pelabuhan perikanan kelas D yaitu seluas $150 \mathrm{~m}^{2}$.

Berdasarkan hasil analisis perhitungan total luas lahan dari seluruh fasilitas maka didapatkan yaitu 1.22 Ha. Berdasarkan Peraturan Menteri Kelautan dan Perikanan No. 8 Tahun 2012 luas lahan untuk memanfaatkan dan mengelola PPI sekurang-kurangnya 1 ha. Sehingga Luas Lahan PPI Beba sudah memenuhi kriteria teknis. 
Berdasarkan hasil analisis luas kolam yang dibutuhkan PPI Beba seluas $1.366 \mathrm{~m}^{2}$. Hasil survey lapangan menunjukkan bahwa hanya beberapa kapal yang menfungsikan kolam pelabuhan disebabkan tidak adanya breakwater yang menahan energi gelombang menimbulkan rasa takut untuk para nelayan berlabuh di kolam pelabuhan karna akan merusak badan kapal. Para nelayan sebagian melabuhkan di tepih pantai sebelah kiri kawasan PPI beba disebabkan kolam pelabuhan yang belum dapat dimanfaatkan secara maksimal.

Berdasarkan Permen KP No. 8 Tahun 2012 untuk PPI kedalaman kolam sekurang-kurangnya minus $1 \mathrm{~m}$. Hasil pengukuran di lapangan didapatkan bahwa kedalaman kolam yaitu $1.7 \mathrm{~m}$. hal ini menunjukkan bahwa kedalaman kolam pada PPI Beba sudah melewati ukuran kebutuhan menurut hasil perhitungan diatas.

Jalan Kawasan PPI Beba sepanjang $107 \mathrm{~m}$, dengan lebar antara 4,3 m, yang digunakan untuk berlalu lintas dan beraktifitas pemakai jasa pelabuhan. Secara umum jalan kawasan di PPI Beba berada dalam kondisi baik a) Drainase memiliki Panjang saluran 51,5 m dan lebar $0,65 \mathrm{~m}$, yang digunakan untuk menampung dan mengalirkan air ke kolam penampungan. b) Lahan/tanah memiliki luas lahan (tanah) seluas $12.200 \mathrm{~m}^{2}$ atau setara dengan $1,22 \mathrm{Ha}$ yang diperuntukkan untuk kepentingan pelayanan umum dan sebagai kawasan industri perikanan dalam peningkatan mutu kuantitas dan kualitas PPI Beba. c) Kolam Pelabuhan PPI Beba tidak memilki pemecah gelombang sebagai fasilitas dasar untuk menahan datangnya gelombang agar kapal - kapal yang berlabuh di PPI tersebut dapat lebih terlindung dari pengaruh gelombang dan ombak yang cukup besar sehingga dapat mempengaruhi aktifitas bongkar muat di PPI ini dan kedalaman Kolam Labuh 1,7 Meter.

Fasilitas fungsional kantor administrasi pelabuhan Pangkalan Pendaratan Ikan Beba memiliki 1 kantor administrasi pelabuhan dengan luas 185 $\mathrm{m}^{2}$ dan memiliki tempat pelelangan ikan (TPI) seluas $210 \mathrm{~m}^{2}$ saat ini masih dalam proses rehabilitasi dan tidak beroperasi, pabrik es di PPI Beba memiliki luas 324 $\mathrm{m}^{2}$. Pabrik es ini berfungsi untuk mencukupi kebutuhan nelayan dalam kegiatan penanganan ikan di pelabuhan dengan kapasitas produksinya 300 balok perhari dan memiliki pasokan air bersih sebanyak $2,5 \mathrm{~m}^{3} /$ bulan yang bersumber dari PDAM. Air bersih yang tersedia cukup untuk keperluan aktivitas yang ada di kantor pelayanan PPI Beba, TPI belum beroperasi dengan optimal sehingga belum menggunakan air bersih yang banyak namun untuk keperluan pabrik es dan cold storage masingmasing menggunakan sumur bor dan air tangki untuk memenuhi kebutuhan masing-masing, sedangkan cold storage dengan kapasitas penampungan sekitar 10 ton dan dilengkapi dengan Pembekuan atau ABF kapasitas 1 ton sebanyak 1 unit yang digunakan untuk penyimpanan dan pembekuan ikan hasil tangkapan masyarakat sekitar Galesong dan telah dilengkapi IPAL dan TPS namun belum beroperasi secara 
maksimal karna masih dalam proses pembangunan. Untuk fasilitas Penunjang sudah dilengkapi dengan MCK dan Pos Jaga.

\section{Analisis Optimalisasi Pemanfaatan Fasilitas PPI Beba}

Berdasarkan hasil analisis optimalisasi untuk fasilitas dermaga PPI Beba adalah 17,28\%. hal tersebut menimbulkan indikasi bahwa pemanfaatan dermaga masih belum optimal, sesuai dengan pernyataan Lubis (2006) yang mengemukakan bahwa nilai persentase dibawah $100 \%$ tingkat pendayagunaan fasilitas belum mencapai optimal. Adapun faktor yang menyebabkan sehingga pemanfaatan belum optimal yaitu dermaga hanya dimanfaatkan kapal para nelayan yang berukuran 30 GT keatas dikarenakan tidak adanya breakwater dan fender yang berfungsi untuk meperlancar aktifitas yang terjadi di dermaga.

Pangkalan Pendaratan Ikan Beba memiliki luas lahan $12.200 \mathrm{~m}^{2}$ atau setara dengan 1,22 Ha. Berdasarkan hasil perhitungan di lapangan lahan yang telah dimanfaatkan di PPI Beba seluas 2.670 $\mathrm{m}^{2}$.tingkat pemanfaatan lahan hanya $21.88 \%$.berdasarkan nilai tersebut lahan kawasan PPI Beba masih termasuk dalam pemanfaatan fasilitas yang belum optimal yaitu nilai yang kurang dari $100 \%$.

Berdasarkan hasil perhitungan tingkat pemanfaatan tempat pelelangan ikan di PPI Beba sebesar 0\%. Persentase tersebut menunjukkan bahwa tingkat pemanfaatan TPI tidak optimal. Tingkat pemanfaatan TPI masih sangat jauh dari nilai 100\%. Hal ini disebabkan tidak adanya kegiatan pelelangan di TPI, karena TPI masih dalam proses pembangunan. Para nelayan menggunakan tepi pantai sebelah kiri sebagai tempat pendaratan dan pelelangan ikan.

Berdasarkan hasil perhitungan tingkat pemanfaatan areal tempat parkir memiliki persentase sebesar $27,8 \%$. Hal ini menunjukkan bahwa cukupnya area parkir sehingga tidak terjadinya penumpukan atau antrian hasil tangkapan yang akan didistribusikan ke luar PPI Beba, akan tetapi arel tempat parkir juga termasuk dalam pemanfaatan fasilitas yang belum optimal.

\section{KESIMPULAN}

Berdasarkan hasil pembahasan dapat disimpulkan beberapa hal sebagai berikut:

1. Fasilitas-fasilitas yang ada di PPI Beba kondisi fisiknya masih baik dan masih layak dipakai, baik itu fasilitas pokok maupun fungsional.

2. Fasilitas-fasilitas yang ada di PPI Beba belum termanfaatan secara optimal didapatkan bahwa lahan PPI Beba 21,88 \%, dermaga $17.28 \%$, dan TPI $0 \%$. Perlu adanya usaha dari pihak pelabuhan, nelayan serta semua pengguna fasilitas di PPI Beba untuk mengoptimalkan pemanfaatan fasilitas PPI di Kabupaten Takalar.

3. Pembangunan breakwater sehingga para nelayan dapat dengan mudah menambatkan kapalnya di dermaga. 


\section{SARAN}

Berdasarkan hasil penelitian yang dilaksanakan di PPI Beba dapat diajukan beberapa saran sebagai berikut:

1. Perlu adanya usaha dari pihak pelabuhan, nelayan serta semua pengguna fasilitas di PPI Beba untuk mengoptimalkan fasilitas PPI di Kabupaten Takalar misalnya dengan mengelola fasilitas yang sudah ada.

2. Adanya peningkatan kualitas pelayanan, peningkatan kualitas SDM, serta pengembangan alat tangkap ramah lingkungan

3. Pembangunan Breakwater sehingga para nelayan dapat dengan mudah menambatkan kapalnya di dermaga.

\section{UCAPAN TERIMA KASIH}

Penulis mengucapkan terima
kasih kepada Dinas Kelautan dan
Perikanan Sulawesi Selatan yang telah
memberikan dukungan untuk
melaksanakan penelitian tesis ini dan
para pembimbing dan reviewer yang
telah banyak memberikan masukan dan
komentar untuk memperbaiki tulisan ini.

\section{DAFTAR PUSTAKA}

Atharis, Y. 2008. Tingkat Kepuasan Nelayan terhadap Pelayanan Penyediaan Kebutuhan Melaut di Pelabuhan Perikanan Samudera (PPS) Bungus Sumatera Barat [Skripsi]. Bogor: Departemen Pemanfaatan Sumberdaya Perikanan, Fakultas Perikanan dan Ilmu Kelautan, Institut Pertanian Bogor. 106 hlm.
[BPS] Sulawesi Selatan, 2017. Sulawesi Selatan dalam Angka. Diterbitkan oleh Badan Pusat Statistik Provinsi Sulawesi Selatan.

Danial., 2003.Optimalisasi Pembangunan Pelabuhan Perikanan di Kawasan Timur Indonesia .Jurnal Ilmiah Prospek. 2(1):157-165.

Danial., 2007. Evaluasi rencana pengembangan pangkalan pendaran ikan (PPI) Soreang ditinjau dari aspek teknis dan biologis di Kota Pare-Pare Sulawesi Selatan. Jurnal Protein. 14(1):93-102.

Lubis. E., 2006. Buku I Pengantar Pelabuhan Perikanan. Bogor: Departemen Pemanfaatan Sumberdaya Perikanan, Fakultas Perikanan dan Ilmu Kelautan, Institut Pertanian Bogor.

Lubis. E., 2012. Pelabuhan Perikanan. Bogor, Institut Pertanian Bogor.

Peraturan Menteri Kelautan dan Perikanan Nomor PER. 08/ MEN / 2012 Tentang Pelabuhan Perikanan

Peraturan Menteri Kelautan dan Perikanan Nomor PER. 16/ MEN / 2006 Tentang Pelabuhan Recovery and Reconstrution

Rangkuti, F. 2002. Analisa SWOT. Teknik Membedah Kasus Bisnis. Gramedia Pustaka Utama, Jakarta.

Rangkuti, F. 2005. Analisis SWOT Teknik Membedah Kasus Bisnis. Gramedia Pustaka Utama, Jakarta. 
Suherman, A. 2007. Rekayasa Model

Pengembangan Pelabuhan

Perikanan Samudera Cilacap

[Disertasi]. Bogor: Sekolah

Pascasarjana, Institut Pertanian

Suherman. A., 2010. Alternatif Pengembangan Pelabuhan

Perikanan Nusantara Brondong Lamongan Jawa Timur. Jurnal Bogor. 307 hlm.

Saintek Perikanan 5 (2) : 65-72. 